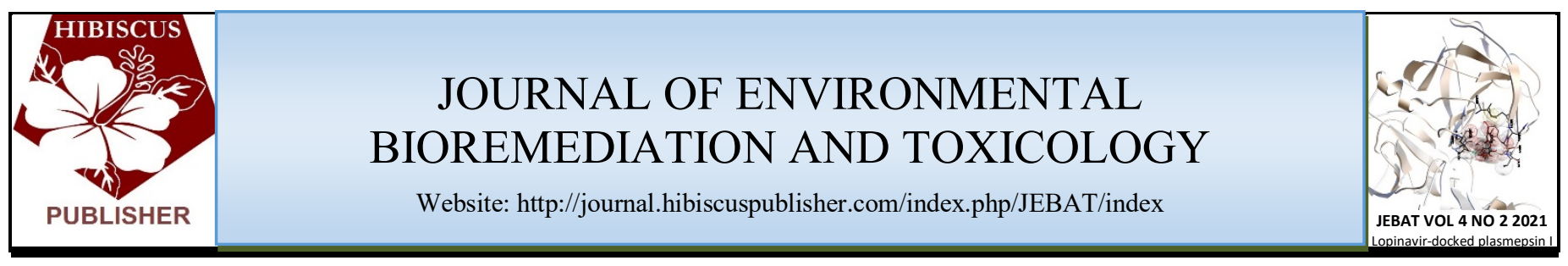

\title{
Effects of Kaduna Refining and Petrochemical Corporation Effluents on the Abundance and Distribution of Phytoplankton Community along River Rido, Kaduna, Nigeria
}

\author{
Dauda, D.M. ${ }^{1}$, Emere, M.C. ${ }^{1}$, Umar, Y. ${ }^{1}$ and A.M. $\mathrm{Umar}^{2 *}$ \\ ${ }^{1}$ Department of Biological Sciences, Faculty of Science, Nigerian Defence Academy, \\ Kaduna, Nigeria. \\ ${ }^{2}$ Department of Biological Sciences, Faculty of Science, Gombe State University, Gombe, Nigeria. \\ *Corresponding author: \\ Dr. A.M Umar, \\ Department of Biological Sciences, \\ Faculty of Science, \\ Gombe State University, \\ Gombe, \\ Nigeria., \\ Email: mububakar@gsu.edu.ng
}

\section{HISTORY}

Received: $24^{\text {th }}$ Oct 2021

Received in revised form: $25^{\text {th }}$ Nov 2021

Accepted: 14th Dec 2021

\section{KEYWORDS}

Effluent

Petroleum wastewater

Phytoplankton

Physicochemical

Rido

\begin{abstract}
The effects of effluent discharged from Kaduna Refining and Petrochemical Corporations (KRPC) on the Phytoplankton species distribution and abundance was studied along river Rido for a period of twelve months from February 2013 to January 2014. A total of Ninety-three (93) species of phytoplankton distributed in five divisions were recorded from four different study stations (A, B, C and D) along the river. Random sequential sampling was employed for selecting a sampling station. Physicochemical parameters were determined in accordance with the standard procedure for wastewater assessment guidelines of American Public Health Association (APHA). Phytoplankton identification was done using appropriate reference materials. The phytoplankton community was dominated by Bacillariophyta 9 constituting $78.98 \%$ with 41 species, followed by Chlorophyta (6.67\%) having 25 species, and then Cyanophyta $(6.46 \%)$ having 12 species, while 10 species of Dinophyta and 5 species of Euglenophyta constituting $5.42 \%$ and $2.49 \%$ respectively were observed. The results from the study revealed low density of phytoplankton in station B, while high density of phytoplankton was observed in stations A and D. The physicochemical parameters showed both seasonal and spatial variations. Values of some parameters studied were observed to be above Federal Environmental Protection Agency (FEPA) limits at station B. Thus, effluent from KRPC is a source of contamination of water quality and adversely affects phytoplankton community along river Rido. Therefore, effluent retention facility should be established for long term treatment of effluent before discharge into the river.
\end{abstract}

\section{INTRODUCTION}

The rapid increase in human population and urbanization causes various freshwater habitats were exposed to anthropogenic distresses leading to aquatic eutrophication[1]. Plankton composition is a vital tool to assess the ecological reliability of aquatic habitats for fish growth and productivity [2]. The freefloating microscopic plants known as Phytoplankton make up the photoautotrophic component of the plankton community and form the major primary producer of organic carbon in the pelagic zone of the seas and of inland waters [3]. They are the base of the food chain in open water bodies and also provide food for organisms that are higher in the trophic levels [4,5]. Phytoplankton play a critical role in primary production, nutrient cycling and food web, and are used in assessing the degree of pollution or as indicators of Pollution of different water bodies due to their very sensitive nature and response to changes in their environment [6-8]. In a fresh water bodies changes in phytoplankton community can result in changes in the fish production and the entire productivity of water, because once the community of plankton change by the effects of pollutants; the structure, stability and function of ecological system can be changed as well. The phytoplankton population of freshwater response to parameters like temperature, dissolved oxygen, $\mathrm{pH}$ and nutrient concentration of the medium and these parameters are influence by the inflow of effluents, sewage and decomposition of waste materials [9].

River Rido like other freshwater bodies is a very important water resource and is used for both domestic and industrial purposes. These include drinking, irrigation, fishing, laundry, bathing, and processes of industrial activities. However, the discharge of industrial effluent into water bodies is one of the main causes of environmental pollution which leads to 
environmental degradation in many communities especially in developing countries [10] and thus put stress on the aquatic biota. Refinery and petrochemical effluents are characterized by the presence of large quantity of polycyclic and aromatic hydrocarbons (PAH), phenols, metal derivatives, sulphides, surface active substances, napthalylenic acids and other chemicals [11].

The content of the effluents have been classified as detrimental to public health, especially where they contain petroleum components such as aliphatic hydrocarbons, heavy metals and polycyclic aromatic hydrocarbon (PAH) [12,13]. Akpan and Offem [14] observed that decrease in productivity of most inland wetlands of the Niger Delta region has been attributed to poor water quality cause by anthropogenic inputs from neighboring communities and oil industries. Achudume [15] reported that fish and aquatic life were absent at the site of effluent discharge from Warri refinery and petrochemical company (WRPC) and at each site downstream to Ubeji River. Kemdirim [16] observed that Kaduna Refining and Petrochemical effluent has negative effect on reduction of the chlorophyll ' $a$ ' and the gross primary productivity particularly at the point of effluent discharge compare to other points downstream along river Rido.

The physico-chemical study of water could also help in understanding of the structure and function of a particular water body in relation to its inhabitant [17]. Lekwot et al. [10] reported that the physicochemical parameters measured in river Romi were higher than the acceptable limit set by National Standard of Nigeria and World Health Organization as a result of contaminants from the effluent discharged into the river. The present study was therefore aim at assessing the effect of effluent discharge by the Kaduna Refining and Petrochemical Corporation (KRPC) on the phytoplankton species abundance and distribution along river Rido, and its effects on the physicochemical factors which have great influence on the biotic community including phytoplankton in an aquatic ecosystem.

\section{MATERIALS AND METHODS}

\section{Study Area}

The study was conducted along river Rido (figure 1), located in Chikun Local Government Area, the outskirts of southern part of Kaduna metropolis, Kaduna state in the North-Western Nigeria. It is located on latitude $10^{\circ} 35^{\prime} \mathrm{N}$ and longitude $07^{0} 28^{\prime} \mathrm{E}$ of the equator. Kaduna state experiences two (2) distinct seasons, dry and wet seasons. River Rido has its origin from Kujama and stretched about $16 \mathrm{~km}$, passes through many communities and runs behind the Kaduna Refining and Petrochemical Corporation and eventually empties into River Kaduna.

\section{Sampling sites}

Random sequential sampling was employed for selecting a sampling stations. Four sampling stations (station A, B, C, and D), were selected for the purpose of this study as follow:

Station A: this is located upstream of the river after Rido town before Kaduna Refining and Petrochemicals Corporation. At that point, the river is deep and moves moderately without much speed and is shaded with few riparian trees. Station A was taken as the control point for the study, due to its clear nature and has no contact with the effluent.

Station B: this is located at the point of discharge of Kaduna Refining and Petrochemical effluent into River Rido. The water is shallow, fast moving, and turbid with surface oil on the water and the area is shaded with trees.
Station C: is the point downstream about $2 \mathrm{~km}$ away from the point of discharge of Kaduna Refining and Petrochemical Cooperation effluent. The water at this point is shallow, open and fast moving.

Station D: this is the point about $4 \mathrm{~km}$ downstream of the river about $4 \mathrm{~km}$ farther away from the point of effluent discharge into the river. At that point, the river is deep, open and moves slowly.

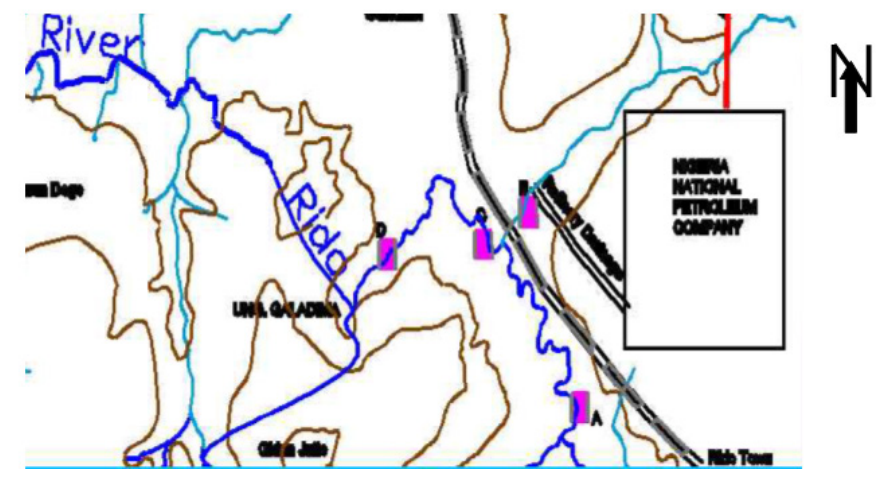

Fig. 1. Four Sampling stations (A, B, C and D) along the river Rido Kaduna State, Nigeria.

\section{Water sampling}

Samples of water were collected early between $8 \mathrm{am}$ to $11 \mathrm{am}$ at each sampling station once monthly for a period of 12 months from February 2013 to January 2014 and analyzed for physicochemical parameters. A clean $4 \mathrm{~L}$ container was used to collect the water sample by lowering it into the river subsurface. Glass bottles were used to collect water samples for trace metals analysis. After labeling, the bottles and jerry cans of the water samples were put inside plastic containers and transported to the Department of Biological Sciences Laboratory, Nigerian Defense Academy (NDA) Kaduna for physicochemical parameters analysis using the methods of [18] and American Public Health Association APHA [19] guidelines.

\section{Determination of Physicochemical parameters}

Physico-chemical parameters were determined in accordance with the standard procedure for waste water assessment guidelines[19]. Temperature and $\mathrm{pH}$ were measured with Microcomputer $\mathrm{pH}$ meter (HI8424 HANNA instrument). Depth of the water was measured with a string tight to a heavy load and lowered into the water. Transparency was measured with black and white Secchi disc. Conductivity and Total Dissolved Solid (TDS) were determined with PHOX 52 combined Conductivity and TDS meter insitu, while Dissolved Oxygen (DO) was measured with Jenway 970 Model waterproof DO meter. Biochemical Oxygen Demand (BOD) was determined by taking differences between initial and final DO after incubation for five (5) days. Chemical Oxygen Demand (COD) was obtained by reflux digestion and titrimetric method (APHA 1998). Spectrophotometer (DR2010 model) was used in determination of Sulphate, Nitrite, Phosphate, Chloride, and Magnesium. Oil \& Grease was determined n-Hexane gravimetric method. Trace metals including Copper, Zinc, Lead (Pb), Nickel (Ni), and Iron $(\mathrm{Fe})$, were determined, after nitric acid $\left(\mathrm{NHO}_{3}\right)$ digestion of the samples, using Atomic Absorption Spectrophotometer (AAS) in line with standard procedure [19].

\section{Plankton sampling}

The Phytoplankton samples were collected by filtering $100 \mathrm{~L}$ of water through the $25 \mu \mathrm{m}$ mesh size plankton net attached to a specimen bottle at the bottom with a ring opening of $10 \mathrm{~cm}$ 
diameter at each sample station. Water was scooped 10 times from the euphotic zone of the river with $10 \mathrm{~L}$ plastic bucket and poured through the wide mouth opening of the plankton net held above the surface of the river. The net was shaken gently and sprayed from outside with tap water to concentrate the organisms at the bottom of the container. The plankton sample in the test tube was then transferred into $50 \mathrm{~mL}$ specimen bottles and preserved by adding 2-3 drops of lugols iodine and closed tightly $[20,21]$.

All the plankton samples were placed inside black nylon container and transported to the Microbiology Laboratory of the Department of Biological Sciences, Nigeria Defense Academy Kaduna, where they were preserved. The samples were transferred into test tube for sedimentation. The test tubes were covered with cover slip and arranged on a rack, and labeled accordingly. The rack was placed on a vibration free surface in the dark cupboard and allowed to stay over a period of $24-48 \mathrm{hrs}$. After then, the supernatant from each plankton sample in the test tube was decanted and the concentrated plankton samples were transferred into a $10 \mathrm{~mL}$ specimen bottle. Distilled water was added up to the plankton sample to make up to $10 \mathrm{~mL}$ suspension[22,23]. The prepared slides were separately mounted on low and high-power compound microscope (Olympus Japan) and viewed using $10 \mathrm{X}, 40 \mathrm{X}, 100 \mathrm{X}$ and $200 \mathrm{X}$ magnifications. Standard keys and monograph [24-28] were used for identification of the phytoplankton species.

\section{Statistical Analysis}

The physico-chemical and biological data generated were subjected to both descriptive and inferential statistical analysis. SPSS version 2010 was employed for the data analysis.

\section{RESULTS AND DISCUSSION}

\section{Physico-chemical parameters in river Rido}

Table 1 shows the mean values of physico-chemical parameters at stations $\mathrm{A}, \mathrm{B}, \mathrm{C}$ and $\mathrm{D}$ in river Rido. The highest average depth of $81.07 \mathrm{~cm}$ was recorded in station A while average lowest depth of $39.78 \mathrm{~cm}$ was recorded in station $B$. The highest mean value of temperature of $30.88{ }^{\circ} \mathrm{C}$ was recorded in station $\mathrm{B}$ and lowest value $\left(24.22{ }^{\circ} \mathrm{C}\right)$ was recorded in station $\mathrm{A}$. The temperature values in all the stations were within permissible limits provided by FEPA and WHO. There was not much variation in mean values of $\mathrm{pH}$ in all the stations. The $\mathrm{pH}$ ranged between 7.19 in station $\mathrm{C}$ and 7.74 in station $\mathrm{D}$. The mean value of Dissolved Oxygen (DO) observed was low (4.77 mg/L) and was recorded in station $\mathrm{B}$, while the highest mean value of $\mathrm{DO}$ was observed in station A $(6.21 \mathrm{mg} / \mathrm{L})$. The mean values of Biochemical Oxygen Demand (BOD) did not show any variation among the study stations and ranged between $3.01 \mathrm{mg} / \mathrm{L}$ in station $\mathrm{A}$ and $3.77 \mathrm{mg} / \mathrm{L}$ in station $\mathrm{C}$.

The mean average Chemical Oxygen Demand (COD) values were very low in all the stations and ranged between 0.02 $\mathrm{mg} / \mathrm{L}$ recorded in station $\mathrm{D}$ and $0.314 \mathrm{mg} / \mathrm{L}$ obtained in station A. The mean value of Alkalinity was highest $(40.29 \mathrm{mg} / \mathrm{L})$ in station B and lowest $(24.921 \mathrm{mg} / \mathrm{L})$ in station $\mathrm{A}$. The average mean values of Total Dissolved Solids (TDS) ranged between $43.75 \mathrm{mg} / \mathrm{L}$ obtained in station A and $224.17 \mathrm{mg} / \mathrm{L}$ obtained in station B.
The mean conductivity was higher in station $\mathrm{B}(334.5 \mathrm{mg} / \mathrm{L})$ and was above permissible limits of FEPA and WHO and the lowest value $63.08 \mathrm{mg} / \mathrm{L}$ was recorded in station A. The mean value of transparency was highest $(30.08 \mathrm{~cm})$ in station A while it was lowest $(12 \mathrm{~cm})$ in station $B$. The highest mean value of Sulphate was recorded in station B $(41.92 \mathrm{mg} / \mathrm{L})$ and lowest value $(8.78 \mathrm{mg} / \mathrm{L})$ was recorded in station $\mathrm{A}$. The mean values of Nitrite ranged between $0.065 \mathrm{mg} / \mathrm{L}$ obtained in station $\mathrm{C}$ and $0.123 \mathrm{mg} / \mathrm{L}$ obtained in station B. The mean value of Magnesium was highest $(205.02 \mathrm{mg} / \mathrm{L})$ in station D and this was above FEPA and WHO permissible limits, while the lowest value of 143.02 $\mathrm{mg} / \mathrm{L}$ was recorded in station $\mathrm{B}$. The mean values of Phosphate ranged between $13.15 \mathrm{mg} / \mathrm{L}$ in station $\mathrm{B}$ and $17.28 \mathrm{mg} / \mathrm{L}$ in station A.

The mean value of Chloride was highest $(31.88 \mathrm{mg} / \mathrm{L})$ in station B and lowest $(13.78 \mathrm{mg} / \mathrm{L})$ in station A. Oil and Grease values ranged between $0.964 \mathrm{mg} / \mathrm{L}$ obtained in station $\mathrm{A}$ and 1.83 $\mathrm{mg} / \mathrm{L}$ obtained in station B. Lead showed gradient decrease downstream in the river from $0.099 \mathrm{mg} / \mathrm{L}, 0.078 \mathrm{mg} / \mathrm{L}$ and 0.068 $\mathrm{mg} / \mathrm{L}$ in station $\mathrm{B}, \mathrm{C}$ and $\mathrm{D}$ respectively and all values were above the permissible limits of FEPA $(0.05 \mathrm{mg} / \mathrm{L})$, except the lowest value $(0.041 \mathrm{mg} / \mathrm{L})$ recorded in station $\mathrm{A}$. The mean values of Nickel, Copper, Zinc and Iron were all insignificant in all the study stations. It was observed that temperature, conductivity, Total Dissolved Solid and Lead in station B were above the permissible limits set by FEPA and WHO (Table 1).

Table 1. Mean values of physico-chemical parameters and heavy metals of River Rido, Kaduna, Nigeria.

\begin{tabular}{|c|c|c|c|c|c|c|}
\hline Physicochemical & Sampli & g Station & & & FEPA* & WHO** \\
\hline & A & B & $\mathrm{C}$ & $\mathrm{D}$ & & \\
\hline Depth $(\mathrm{cm})$ & 81.07 & 39.78 & 74.83 & 75.54 & NS & NS \\
\hline Temperature ${ }^{0} \mathrm{C}$ & 24.22 & 30.88 & 25.58 & 26.00 & 30 & 30 \\
\hline $\mathrm{pH}$ & 7.22 & 7.29 & 7.19 & 7.74 & $6.5-8.5$ & $6.5-8.5$ \\
\hline D.O $(\mathrm{mg} / \mathrm{L})$ & 6.21 & 4.77 & 5.98 & 5.38 & 10 & 10 \\
\hline $\mathrm{BOD}(\mathrm{mg} / \mathrm{L})$ & 3.01 & 3.38 & 3.77 & 3.57 & 10 & 10 \\
\hline $\mathrm{COD}(\mathrm{mg} / \mathrm{L})$ & 0.03 & 0.02 & 0.026 & 0.02 & 40 & 40 \\
\hline Alkalinity $(\mathrm{mg} / \mathrm{L})$ & 24.92 & 40.29 & 29.54 & 30.71 & NS & 600 \\
\hline TDS (mg/L) & 43.75 & 224.17 & 108.42 & 120.58 & 200 & 250 \\
\hline Conductivity $(\mu \mathrm{S} / \mathrm{cm})$ & 63.08 & 334.50 & 155.75 & 172.25 & 240 & 250 \\
\hline Transparency $(\mathrm{cm})$ & 30.28 & 12.00 & 26.09 & 26.47 & NS & NS \\
\hline Sulphate $(\mathrm{mg} / \mathrm{L})$ & 8.78 & 41.92 & 23.33 & 17.33 & 500 & 400 \\
\hline Nitrite $(\mathrm{mg} / \mathrm{L})$ & 0.11 & 0.13 & 0.07 & 0.08 & NS & NS \\
\hline Magnesium (mg/L) & 165.92 & 143.02 & 196.66 & 205.23 & 200 & 150 \\
\hline Phosphate $(\mathrm{mg} / \mathrm{L})$ & 17.28 & 13.15 & 14.18 & 15.65 & 5 & 10 \\
\hline Chloride $(\mathrm{mg} / \mathrm{L})$ & 12.78 & 31.88 & 14.99 & 16.47 & 200 & 250 \\
\hline Oil \& Grease $(\mathrm{mg} / \mathrm{L})$ & 0.96 & 1.83 & 1.25 & 1.59 & 10 & NS \\
\hline Lead $\mathrm{Pb}(\mathrm{mg} / \mathrm{L})$ & 0.04 & 0.10 & 0.08 & 0.07 & 0.05 & $<1$ \\
\hline Nickel Ni $(\mathrm{mg} / \mathrm{L})$ & 0.12 & 0.097 & 0.12 & 0.13 & $<1$ & $<1$ \\
\hline Copper $\mathrm{Cu}(\mathrm{mg} / \mathrm{L})$ & 0.020 & 0.026 & 0.02 & 0.01 & 1.5 & $<1$ \\
\hline Zinc $\mathrm{Zn}(\mathrm{mg} / \mathrm{l})$ & 0.009 & 0.009 & 0.01 & 0.01 & 1 & $<1$ \\
\hline Iron $\mathrm{Fe}(\mathrm{mg} / \mathrm{l})$ & 0.118 & 0.067 & 0.09 & 0.11 & 1 & 1 \\
\hline
\end{tabular}

\section{Phytoplankton species identified in River Rido}

The results of phytoplankton species identified in Rido River over a period of 12 months is presented in Table 2. The Table revealed a total number of 93 phytoplankton species identified in 5 major classes of phytoplankton. Bacillariophyta had the highest number of 41 phytoplankton species identified, followed by Chlorophyta with 25 species identified, Cyanophyta had 12 species, whereas Dinophyta and Euglenophyta were represented by 10 and 5 phytoplankton species respectively. 
Table 2. The phytoplankton species identified in River Rido Kaduna, Nigeria.

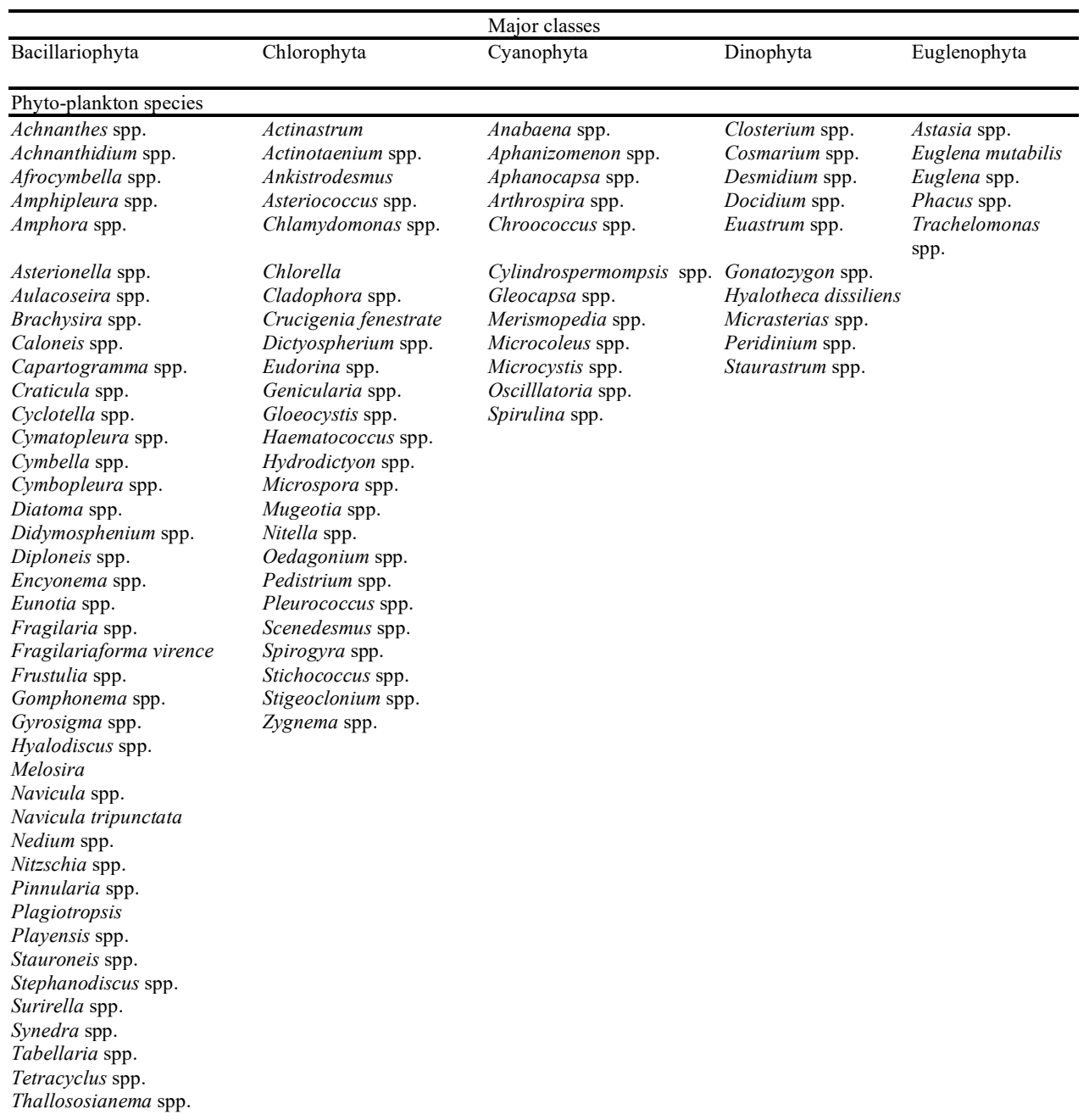

\section{Relative abundance of phytoplankton in Rido River}

The relative abundance of major phytoplankton classes in Rido River is displayed in Fig. 2. There was higher relative abundance of phytoplankton in station A with the exception of Cyanophyta which shows higher relative abundance in Station D and least relative abundance of phytoplankton in station B in all the classes of phytoplankton under investigation.

\section{DISCUSSION}

The high values of temperature, TDS, conductivity and chloride recorded at station $\mathrm{B}$ could be the resultant pollutant content of the effluent discharged, while the low values of transparency and depth observed could be due to presence of suspended particles as well as shallowness of the river at station B. However, it was noted that there was dilution and self-purification process by the river downstream as distance from the effluent entry point increased and thus increase in the density of phytoplankton downstream was observed. Egborge [29] reported that increasing levels of dissolved oxygen in aquatic systems are usually associated with eutrophic and productive water bodies. This corresponds to high density of phytoplankton, and thus high primary productivity which might in turn lead to high dissolved oxygen concentration [30].
The high transparency observed in stations A and D, could be due to low TDS, and suspended particles which interfere with light intensity and could also be due to reduction in suspended substances and allochtonous substance that find their ways into the water with flood [31]. The high concentration of chloride in stations $\mathrm{C}$ and $\mathrm{D}$ could be due to high fertilizer and nutrient loading washed into the river by rain runoff from agricultural farmland. Higher concentration of chloride in fresh water is an indication of organic pollution [32]. In the freshwater environment, low availability of phosphate is one of the several factors which cause a decline in primary productivity. Dissolved orthophosphate is one of the nutrient sources for phytoplankton as it is taken rapidly by phosphorus deficient cells until very low concentrations remain in the water [33]. The low mean value of DO obtain in station B could be due to higher load of organic matter from the effluent received. Lower DO value has a serious consequence on the proper functioning of the aquatic body and can lead to death of aquatic organisms including fish. 


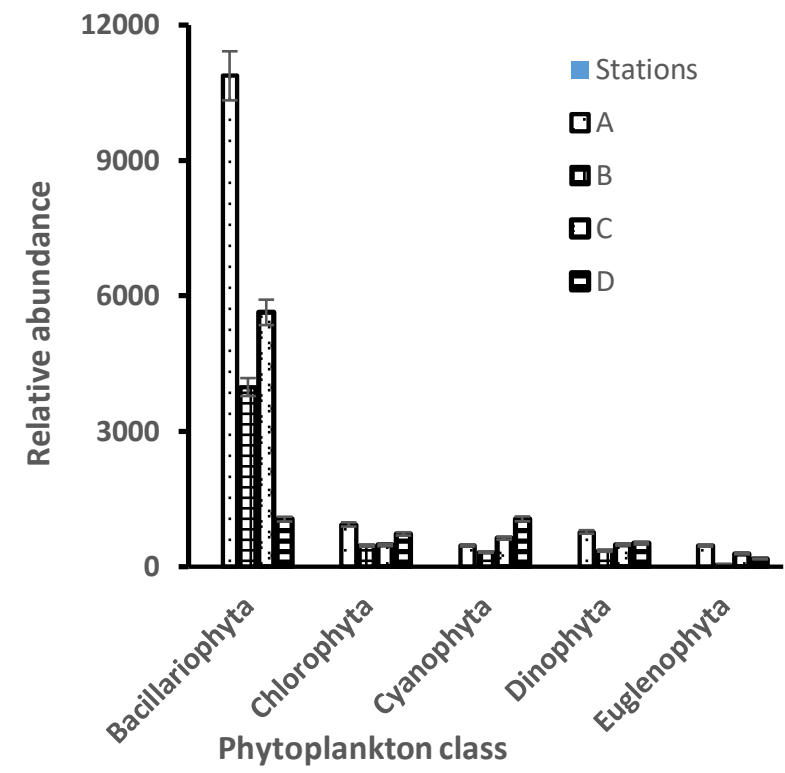

Fig. 2. Relative abundance of phytoplankton in River Rido, Kaduna Nigeria.

The high values of phosphate (above FEPA and WHO permissible limits) could lead to Eutrophication and bring about high primary productivity and result in algal bloom which causes subsequent poor water quality and result in fish kills [34]. The high values of lead recorded in all the stations, except station Athe control point, was a discernable indication of effluents manifestation in the aquatic environment, particularly as the highest concentration recorded value was obtained at the point of effluent discharge from the Refinery.

The recorded values of Conductivity and magnesium which were above the FEPA and WHO level in station B and D have shown the high presence of dissolved ions in the water which could be received directly from the effluent discharge point as well as the adjacent farmland around the bank of the river. Also, the higher values of some of the physico-chemical parameters such as temperature, conductivity, TDS and sulphate (above permissible limit by FEPA and WHO), chloride, oil and grease as well as the relative low values of DO, transparency and phosphate recorded at station $\mathrm{B}$ showed that the effluent contributed significantly toward pollutants loading which induced alteration and impairment of the physico-chemical properties and consequent deleterious effects to the planktons community and other aquatic biota.

The order of phytoplankton abundance and distribution Bacillariophyta >Chlorophyta >Cyanophyta $>$ Dinoflagellates $>$ Euglenophyta is similar to the observations reported from Oyun reservoir [35]. The dominance and high density of Bacillariophyta was similar to the result obtained from the study of Khan and Ejike [36] in Plateau reservoir and might be attributed to their high rate of reproduction within a short period of time. The species with the highest self-sustaining natural mechanisms of increase usually become dominant in the environment [37,38]. This may account for high density and dominance of Bacillariophyta in some freshwater bodies such as river Rido. Also, the presence of Chlorophyta which is next to Bacillariophyta in abundance may be due to availability of nutrients such as phosphate and nitrogen which are essential for phytoplankton growth [39]. The low abundance of Euglenophyta could be due to its preferences of brackish water or high saline water [35].
Opute [40] reported that Dinoflagellates and Euglenophyta are often not significantly abundant in Nigerian fresh water. There was high abundance and distribution of planktons at station A and $\mathrm{D}$ compared to station $\mathrm{C}$, while station $\mathrm{B}$ which had the lowest abundance of plankton species. This might be adduced to the facts that station B which is closer to the point of entry of the refinery effluent, might have been contaminated by the effluent thereby becoming unfavorable for the survival and reproduction of planktons. This finding is in line with the observation made by Kemdirim [16] that the effects of the effluent discharge by KRPC into river Rido decrease as the distance from the point of entry of the effluent increased and the area with high concentration of effluent has low density of primary productivity. Ogbeibu and Edutie [41] stated that sensitive species disappeared at the site of pollution while tolerant ones survive pollution stress and readily recover downstream in the river. Also, the impact of the effluent as observed from the result decreases as the distance from the point of effluent discharge increases downstream in the river. The finding showed that there was increase in the density of planktons from station B to C and then D downstream in the river. This could be as a result of recovery and natural purification capability of the river as had been also observed by [42].

The presence of pollution indicator algae such as Navicula spp., Nitzschia spp., Scenedesmus spp. Oscillatoria spp., Microcystist spp., Euglena spp. etc. identified in all the stations is an indication of organic pollutant present in the environment [43]. This also indicated high nutrient loading and alkaline $\mathrm{pH}$ which could influence high phytoplankton production and growth and increase of the primary production in the river [33].

\section{CONCLUSION}

The Kaduna Refining and Petrochemical Corporation effluent discharged into river Rido resulted in decreased density of phytoplankton population at the area around the point of entry, but the effects decreased as the distance increases farther away from the point of discharge downstream into the river. The variation in some of the physico-chemical parameters such as Depths, Transparency, Temperature, Total Dissolved Solids, Conductivity, and Chloride, between other stations with the station located near effluent discharge point has indicated adverse effects of the effluent in the water. Also, the identification of organic pollutant indicator algal species such as Navicula spp., Nitzschia spp., Scenedesmus spp., Oscillatoria spp., Microcystist spp., Euglena spp. among others is evidence of organic pollution of river Rido due to pollution discharge from the Kaduna Refining and Petrochemical Corporation.

\section{REFERENCES}

1. Ibrahim A, Capo E, Wessels M, Martin I, Meyer A, Schleheck D, et al. Anthropogenic impact on the historical phytoplankton community of Lake Constance reconstructed by multimarker analysis of sediment-core environmental DNA. Mol Ecol. 2021;30(2020):3040-56.

2. Udeme EJ, Samuel EE. Preliminary Study on the Diversity of Plankton Flora and Water Quality of a Tropical Mangrove Estuarine System, Akwa Ibom State, Niger Delta Area, Nigeria. African Journal of Environment and Natural Science Research 2020; 3(6):34-45.

3. Reynold C. Ecology of Phytoplankton: Ecology, Biodiversity and Conservation. Cambridge University Press, UK.; 2006. PP 551.

4. Onyema IC, Popoola RT. The Physico-Chemical Characteristics, Chlorophyll a Levels and Phytoplankton Dynamics of the East Mole Area of the Lagos Harbour, Lagos. J Asian Sci Res. 2013;3(10):995-1010. 
5. Ganai AH, Parveen S. Effect of physico-chemical conditions on the structure and composition of the phytoplankton community in Wular Lake at Lankrishipora, Kashmir. Int J Biodivers Conserv. 2013;6(1):71-84.

6. Trivedy RK, Goel PK. Chemical and biological methods for water pollution studies, Environmental Publication, Karad India. 1986. $251 \mathrm{pp}$.

7. Sudhaker G, Joyothi B, Venkateswarlu V. Role of diatom as indicator of polluted gradients. J Environ Monit Assess. 1994;33:85-99.

8. Dwivedi BK, Pandey GC. Physicochemical factors and algal diversity of two ponds (Girija Kund and Maqubara Pond), Faizabad. India Pollut Res. 2002;21(3):361-369.

9. Jafari N, Alavi SS. Phytoplankton community in relation to physico-chemical characteristics of the Talar River, Iran. J Appl Sci Environ Manag. 2010;14(2):51-6.

10. Lekwot V, Chikogu V, Adamu I. Public Health Effects of Effluent Discharge of Kaduna Refinery into River Romi. Greener J Med Sci. 2012;2(3):064-9.

11. Suleimanov AY. Conditions of Waste Fluid Accumulation at Petrochemical and Processing Enterprise Prevention of their Harm to Water Bodies" . Meditsina Tr PromysweNnaia Ekol. 1995;12:31-6.

12. Ogbuagu D, Ayoade A. Seasonal Dynamics in Plankton Abundance and Diversity of a Freshwater Body in Etche, Nigeria Dike Henry. Environ Nat Resour Res. 2012;2(2):48-59.

13. Mbaneme FCN, Okoli CG, Ekweghi C. The Impact of refinery effluent in the physiochemical regime of Ekerekana creek in Okirika mainland, rivers state, Nigeria. Am J Environ Energy Power Res. 2013;1(10):255-71.

14. ER A, Offem J. Seasonal variation in water quality of the Cross River State Nigeria. Hydrobiologia. 1993;26:95-103.

15. Achudume AC. The Effect of Petrochemical Effluent on the Water Quality of Ubeji Creek in Niger Delta Region. Bull Environ Toxicol. 2009;83:410-5.

16. Kemdrim EC. The effects of Refinery effluent on the reduction of chlorophyll ' $\mathrm{a}$ ' and gross primary productivity in river Rido. $\mathrm{J}$ Aquat Sci. 1994;14:43-6.

17. Abubakar UM, Umar DM, Zainab MZ. Effects of Some Physicochemical Parameters on Oreochromis niloticus in Dadin Kowa Reservoir Gombe State Nigeria. Int J Adv Chem Eng Biol Sci. 2015;2(2):110-2.

18. Sutherland WJ. Ecological Census Techniques. A Handbook. Cambridge.: Cambridge University Press,; 1997. 336pp.

19. (APHA) APHA. Standard Methods for the Examination of Water and Wastewater. Washington D. C.; 1998 p. 1213.

20. Ramachandra TV, Solanki M. Ecological assessment of Lentic Water bodies of Bangalore, ENVIS Technical Report 25, Environmental Information System, Centre for Ecological Sciences, Bangalore. 2007.

21. Edward JB, Ugwumba AAA. Physico-Chemical Parameters and Plankton Community of Egbe Reservoir, Ekiti State, Nigeria. Res J Biol Sci. 2010;5:356-67.

22. Verlencar XN, Desai S. Phytoplankton Identification Manual. National Institute of Oceanography Dona Paula, Goa - 403 004.; 2004 p. 40 pp.

23. Onyema IC. The phyloplankton composition abundance and temporal variation of a polluted estuarine creek in Lagos, Nigeria. Turk J Fish Aquat Sci. 2007;7:89-96.

24. Edmondson W. Freshwater Biology. 2nd Ed. New York: Johan Wiley \& Sons Inc.,; 1959. 1248 p.

25. Needham JG, Needham P. A Guide to the Study of Freshwater Biology. 2nd Editio. Holden-Day Inc., San Francisco, C.A.; 1962. 108 pp.

26. Prescott GW. How to Know Freshwater Algae. 3rd Edn. USA: WMC Brown Company; 1978. 293 pp.

27. Janse VVS, Taylor J, Gerber N, Van GC. Easy identification of the most common freshwater algae: A guide for the identification of microalgae in South African freshwater. 2006. 211pp.

28. Bellinger EG, Sigee DC. Freshwater Algae: Identification and Use as Bioindicators. Wiley \& Sons, Limited; 2010. 138-253 p.

29. Egborge ABM. Salinity and the distribution of rotifers in the Lagos Habour - Badagry creek system, Nigeria. Hydrobiologia. 1994;272:95-104.
30. Mason CF. Biology of Fresh Water Pollution. 2nd Editio. New York: Wesley and Sons Inc.; 1991. $351 \mathrm{pp.}$

31. Ikom RB, Iloba KI, Ekure MA. The Physical and Chemical Hydrology of River Adofi at Utagba-Uno, Delta State, Nigeria. The Zoologist. 2003;2(2):84-95.

32. Rajanna AH, Belagali SL. Variations in phytoplankton abundance with respect to pollution profile of Kabini river at Nanjangud. J Environ Sci Comput Sci Eng Technol. 2014;3(1):111-23.

33. Celia YH, Edward GD. Effect of $\mathrm{pH}$ on the growth and carbon uptake of marine phytoplankton. Mar Ecol Prog Ser. 1994;190:8394.

34. Annune PA, Ahuma FTA. Haematological changes in mudfish, Claries gariepinus (Burch) exposed to sublethal concentration of copper and lead. J Aquat Sci. 1998;13:33-6.

35. Mustapha MK. Seasonal Influence of Limnological Variables on Plankton Dynamics of a Small, Shallow, Tropical African Reservoir. Asian J Exp Biol Sci. 2010;1(1):60-79.

36. Khan MA, Ejike C. Limnology and plankton periodicity of Jos plateau water reservoir Nigeria, West Africa. Hydrobiologia. 1984;114:189-199.

37. Abowei JFN, Tawari CC, Hart AI, D.U. G. Phytoplankton and physico- chemical characteristics in the lower sombreiro river, Niger Delta, Nigeria. Afr J Appl Zool Environ Biol. 2008;10:11-9.

38. Davies OA, Abowei JFN, Otene BB. Seasonal abundance and distribution of plankton of Minichinda stream, Niger Delta, Nigeria. Am J Sci Res. 2009;2:20-30.

39. Talling JF, Lemoalle J. Ecological Dynamics of Tropical Inland Waters. Cambridge: Cambridge University Press; 1998. 441 pp.

40. Opute F. Contributions to the knowledge of algae of Nigeria I. Desmids from the Warri/Forcados Estuaries. Part II. The elongate baculiform desmids. J Limnol. 2000;59(2):131-55.

41. Ogbeibu A, Edutie L. Impact of the brewery effluent on the water Quality and rotifer of Ikpoba River, southern Nigeria. Afr J Environ Pollut Health. 2002;1(1):1-12.

42. Machena C. The self-purification capacity of the Mukuvisi river. In: N.A.G Moyo (Eds) Lake Chivero, a polluted lake. University of Zimbabwe Publications, Harare, Zimbabwe. 1997.

43. Zargar S, Ghosh TK. Influence of cooling water discharges from Kaiga nuclear power plant on selected indices applied to plankton population of Kadra reservoir. J Environ Biol. 2006;27:91-198. 